\title{
Iron overload in Brazilian thalassemic patients
}

\author{
Sobrecarga de ferro em pacientes talassêmicos brasileiros
}

\begin{abstract}
Reijane Alves de Assis ${ }^{1}$, Fernando Uliana Kay², Laércio Alberto Rosemberg², Alexandre Henrique C. Parma ${ }^{2}$, Cesar Higa Nomura $^{2}$, Sandra Regina Loggetto ${ }^{3}$, Aderson da Silva Araujo ${ }^{4}$, Antonio Fabron Junior ${ }^{5}$, Mônica Pinheiro de Almeida Veríssimo ${ }^{6}$, Giorgio Roberto Baldanzi ${ }^{7}$, Merula A. Steagal ${ }^{8}$, Claudia Angela Galleni Di Sessa Velloso ${ }^{8}$, Breno Pannia Espósito ${ }^{9}$, Sandra Saemi Nakashima ${ }^{10}$, Michelli da Silva Diniz ${ }^{10}$, Fernando Tricta ${ }^{11}$, Ronaldo Hueb Baroni ${ }^{2}$, Marcelo Buarque de Gusmão Funari ${ }^{2}$, John C. Wood ${ }^{12}$, Andreza Alice Feitosa Ribeiro ${ }^{13}$, Nelson Hamerschlak ${ }^{1}$
\end{abstract}

\begin{abstract}
Objectives: To evaluate the use of magnetic resonance imaging in patients with $\beta$-thalassemia and to compare $\mathrm{T} 2 *$ magnetic resonance imaging results with serum ferritin levels and the redox active fraction of labile plasma iron. Methods: We have retrospectively evaluated 115 chronically transfused patients (65 women). We tested serum ferritin with chemiluminescence, fraction of labile plasma iron by cellular fluorescence and used T2* MRI to assess iron content in the heart, liver, and pancreas. Hepatic iron concentration was determined in liver biopsies of 11 patients and the results were compared with liver T2* magnetic resonance imaging. Results: The mean serum ferritin was $2,676.5+/-2,051.7 \mathrm{ng} / \mathrm{mL}$. A fraction of labile plasma iron was abnormal (> 0,6 Units $/ \mathrm{mL}$ ) in 48/83 patients (57\%). The mean liver T2* value was $3.91 \pm 3.95 \mathrm{~ms}$, suggesting liver siderosis in most patients $(92.1 \%)$. The mean myocardial T2* value was $24.96 \pm 14.17 \mathrm{~ms}$ and the incidence of cardiac siderosis (T2* $<20 \mathrm{~ms}$ ) was $36 \%$, of which $19 \%$ (22/115) were severe cases (T2* $<10 \mathrm{~ms}$ ). The mean pancreas $\mathrm{T}^{*}$ value was 11.12 $\pm 11.20 \mathrm{~ms}$, and $83.5 \%$ of patients had pancreatic iron deposition $\left(\mathrm{T}^{*}<\right.$ $21 \mathrm{~ms})$. There was significant curvilinear and inverse correlation between liver $\mathrm{T}^{*}$ magnetic resonance imaging and hepatic iron concentration $(r=-0.878 ; p<0.001)$ and moderate correlation between pancreas and myocardial T2* MRI $(r=0.546 ; p<0.0001)$. Conclusion: A high
\end{abstract}

rate of hepatic, pancreatic and cardiac impairment by iron overload was demonstrated. Ferritin levels could not predict liver, heart or pancreas iron overload as measured by $\mathrm{T}^{*}$ magnetic resonance imaging. There was no correlation between liver, pancreas, liver and myocardial iron overload, neither between ferritin and fraction of labile plasma iron with liver, heart and pancreas T2* values

Keywords: Blood transfusion; Magnetic resonance imaging; Biopsy; Iron overload

\section{RESUMO}

Objetivo: Avaliar o acúmulo de ferro em diferentes órgãos por meio da ressonância nuclear magnética $\mathrm{T}^{*}$ e correlacionar os resultados aos níveis de ferritina sérica, ferro plasmático lábil e outros órgãos envolvidos. Métodos: Foram avaliados retrospectivamente 115 pacientes talassêmicos (sendo 65 mulheres). A concentração hepática de ferro foi determinada em biópsia de 11 pacientes; os resultados foram comparados com os valores de T2* fígado. Resultados: a ferritina sérica média foi de 2.676,5+/- 2.051,7 ng/mL. 0 ferro plasmático lábil foi anormal ( $>0,6$ Unidades $/ \mathrm{mL}$ ) em $48 / 83$ pacientes (57\%). A média dos valores de T2* no fígado foi 3,91 $\pm 3,95$ ms, sugerindo siderose hepática

Study carried out at Hematology and Bone Marrow Transplantation, Hospital Israelita Albert Einstein - HIAE - São Paulo, Brazil; Department of Imaging, Hospital Israelita Albert Einstein - HIAE - São Paulo (SP), Brazil; Centro de Hematologia de São Paulo - CHSP - São Paulo (SP), Brazil; Pernambuco Blood Center - Recife (PE), Brazil; Marilia Blood Center - Marilia (SP), Brazil; Boldrini Children Center - Campinas (SP), Brazil; Parana Blood Center - HEMEPAR - Curitiba (PR), Brazil; Brazilian Association of Thalassemia - ABRASTA - São Paulo (SP), Brazil; Chemistry Institute at Universidade de São Paulo - USP - São Paulo (SP),

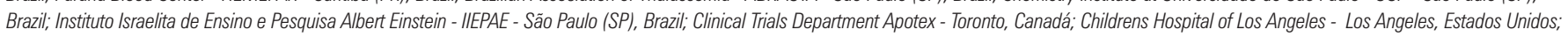
Blood Bank, Hospital Israelita Albert Einstein - HIAE - São Paulo (SP), Brazil.

${ }^{1}$ Hematology and Bone Marrow Transplantation, Hospital Israelita Albert Einstein - HIAE - São Paulo, Brazil

${ }^{2}$ Department of Imaging, Hospital Israelita Albert Einstein - HIAE - São Paulo (SP), Brazil.

${ }^{3}$ Centro de Hematologia de São Paulo - CHSP - São Paulo (SP), Brazil.

${ }^{4}$ Pernambuco Blood Center - Recife (PE), Brazil.

${ }^{5}$ Marilia Blood Center - Marilia (SP), Brazil.

${ }^{6}$ Boldrini Children Center - Campinas (SP), Brazil.

${ }^{7}$ Parana Blood Center - HEMEPAR - Curitiba (PR), Brazil.

${ }^{8}$ Brazilian Association of Thalassemia - ABRASTA - São Paulo (SP), Brazil.

${ }^{9}$ Chemistry Institute at Universidade de São Paulo - USP - São Paulo (SP), Brazil.

${ }^{10}$ Instituto Israelita de Ensino e Pesquisa Albert Einstein - IIEPAE - São Paulo (SP), Brazil.

${ }^{11}$ Clinical Trials Department Apotex - Toronto, Canada.

${ }^{12}$ Childrens Hospital of Los Angeles - Los Angeles, Estados Unidos.

${ }^{13}$ Blood Bank, Hospital Israelita Albert Einstein - HIAE - São Paulo (SP), Brazil; Hematology and Bone Marrow Transplantation, Hospital Israelita Albert Einstein - HIAE - São Paulo, Brazil.

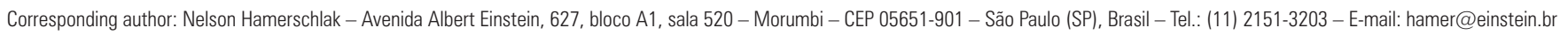
Received on: Oct 10, 2010 - Accepted on: April 12, 2011

Conflict of interest: none 
em $92,1 \%$ pacientes. A média do $\mathrm{T}^{*}$ cardíaco foi de $24,96 \pm 14,17 \mathrm{~ms}$ e $36 \%$ dos pacientes apresentavam siderose cardíaca $\left(T 2^{*}<20 \mathrm{~ms}\right)$, dos quais $19 \%(22 / 115)$ já apresentavam sobrecarga cardíaca grave $\left(\mathrm{T}^{*}{ }^{*}<\right.$ $10 \mathrm{~ms}$ ). A média de T2* no pâncreas foi de 11,12 $\pm 11,20$ ms, perfazendo um total de $83,5 \%$ de pacientes com sobrecarga de ferro pancreático ( $\left.\mathrm{T} 2^{*}<21 \mathrm{~ms}\right)$. Houve correlação significativa, curvilínea e inversa entre T2* fígado e a concentração de ferro hepática $(r=-0,878 ; p<0,001)$ e correlação moderada entre T2* pâncreas e T2* miocárdio $(r=0,546 ; p$ $<0,0001)$. Não houve correlação entre o fígado e o pâncreas ou o fígado e o coração, bem como entre ferritina e ferro plasmático lábil com valores de T2* dos três órgãos. Conclusão: Uma elevada taxa de acometimento hepático, pancreático e cardíaco por sobrecarga férrica foi demonstrada. Os níveis de ferritina não puderam prever sobrecarga de ferro hepático, cardíaco ou pancreáticos medidos por meio da ressonância nuclear magnética T2* ${ }^{*}$ Não houve correlação entre a sobrecarga de ferro no fígado, pâncreas e miocárdio, nem entre a ferritina e os níveis plasmáticos de ferro sérico e os valores de T2* no fígado, coração e pâncreas.

Descritores: Transfusão de sangue; Imagem por ressonância magnética; Biópsia; Sobrecarga de ferro

\section{INTRODUCTION}

Beta-thalassemias are caused by mutations of the genes that codify the synthesis of $\beta$-globin chains, reducing or eliminating their synthesis. The relative excess of $\alpha$-globin chain synthesis leads to increase in apoptosis of erythroid precursors, causing ineffective erythropoisis, extramedullary expansion and spleen enlargement $t^{(1,2)}$. In addition to reduction of red blood cell survival, these abnormalities lead to anemia. In subjects with severe to moderate forms of $\beta$-thalassemia, there is increase in the intestinal absorption of iron. Iron intestinal absorption, as well as its recycling, is regulated by hepcidine. The concentration of hepcidine is low in holders of $\beta$-thalassemia and it does not increase regardless of red blood cell transfusions given to these subjects. Low levels of hepcidine stimulate iron absorption and store ${ }^{(1)}$.

Iron is habitually transported by transferrin bounds and it typically binds to $30 \%$ of all binding sites in this protein. Patients with $\beta$-thalassemia may develop iron stores beyond the binding capacity of iron carrying proteins, generating an excess of labile plasma iron (LPI). This free iron causes oxidative stress in tissues, resulting in morbidity and mortality ${ }^{(1)}$.

Beta-thalassemia is prevalent in populations in the Mediterranean, Middle East, Transcaucasus, Central Asia, Indian Subcontinent, and Far East. It is also common in populations of African heritage. The high gene frequency of $\beta$-thalassemias in these regions is most likely related to the selective pressure from malaria. This distribution is quite similar to that of endemic Plasmodium falciparum malaria. However, because of population migration and, in a limited part, the slave trade, $\beta$-thalassemia is now also common in northern
Europe, North and South America, the Caribbean, and Australia ${ }^{(2,3)}$.

It is estimated to have nearly 500 patients with major $\beta$-thalassemia in Brazil; however, these figures are considered underestimated given that according to them the patients are concentrated in South, Southeastern and Center-West regions ${ }^{(4)}$.

Regular transfusion to maintain the hemoglobin level at about 9 to $10 \mathrm{~g} / \mathrm{dL}$ started to be used in 1960's, as standard treatment for patients with thalassemia major and in some cases of thalassemia intermedia. This therapy had provided good short-time quality of life, but the deaths by iron transfusion overload affected mainly subjects who were aged 12 to 24 years $^{(5)}$.

Patients received on average 3 units of red cell concentrates, within 3 to 4 week intervals, totaling 39 units of red blood cells/year. It is estimated that each unit contains about 200 to $250 \mathrm{mg}$ of iron. Therefore, it is calculated that the average accumulation of iron is $7.8 \mathrm{~g}$ at the end of 1 year, in addition to intestinal absorption. The human body does not have mechanisms for iron excretion. The chronic use of regular transfusions cause iron overload and damage to different organs, such as the heart, liver, spleen, pancreas, hypophysis, brain and bone marrow ${ }^{(6)}$.

To present, the most common cause of death in patients with thalassemia major is heart failure secondary to iron overload. This cardiopathy may be prevented or reverted if drugs that reabsorb iron stored in tissues are used. However, the diagnosis of abnormal iron stores by echocardiogram and electrocardiogram will detect abnormalities only when the patients already have symptoms ${ }^{(7,8)}$.

The therapeutic decision to use and follow up the chelating agents based on ferritin levels is not always directly correlated with lab results and tissue iron deposit levels. In many situations, ferritin levels may express inflammatory situations or even liver damage ${ }^{(9)}$.

Magnetic resonance imagining (MRI) $\mathrm{T} 2 *$ has been used as a direct method to monitor myocardial iron deposits, in addition to deposits in the liver and other tissues. Many studies have shown its high predictive value to detect early iron deposits in these organs, before tissue damage impairs their functioning ${ }^{(7-11)}$.

\section{OBJECTIVE}

To describe the results found by MRI T2* in measuring heart, liver and pancreas iron stores, using a measurement technique of T2*, as well as the correlations with serum levels of ferritin and LPI in the Brazilian population of thalassemic patients, which had never been studied by this methodology. 


\section{METHODS}

\section{Study design and population}

The results of the first MRI performed by 115 patients were analyzed (102 with thalassemia major and 13 with thalassemia intermediate, dependent of transfusion) between March 2004 and August 2007.

All patients signed a free informed consent term as approved by the Research Ethics Committee of the Hospital Israelita Albert Einstein.

\section{Magnetic Resonance Imaging}

All MRI were performed at Hospital Israelita Albert Einstein (HIAE) in São Paulo (SP).

A $1.5 \mathrm{~T}$ MR imaging system (General Electric, Milwaukee, Wisconsin, USA) was used for T2* imaging and iron quantification. Heart imaging data (functional analysis and $\mathrm{T}^{*}$ ) were analyzed using the ReportCard V3.3 software (General Electric, Milwaukee, Wisconsin, USA).

All patients underwent multiecho (8 echoes, echo space of $8 \mathrm{~mm}$ ) gradient echo MRI sequences for the heart (short axis view), and in the axial plane of the upper abdomen for liver, pancreas and spleen. Regions of interest (ROIs) for $\mathrm{T}^{*}$ calculation were traced in the cardiac interventricular septum, liver, pancreas and spleen parenchyma. Paraspinal musculature was also assessed for the analysis and the ratio of signal intensity (SIR) in pancreas/paraspinal muscle on $\mathrm{T}^{*}$. Left ventricular ejection fraction (LVEF) was measured by standard MRI techniques.

The MRI signal intensity decays over crescent echo times were measured. Iron overloaded tissue darkens quicker and the half-life of the signal decay (darkening of the image) was used to quantify iron content. The result was expressed in milliseconds (ms), such as T2* times. Shorter T2* relates to higher tissue iron content.

The normal values of $\mathrm{T} 2 *$ for the liver, pancreas and the heart used in the study were based on data from previous studies ${ }^{(12,13)}$.

Pancreatic iron overload was estimated through the correlation between each patient's own pancreatic and paraspinal musculature $\mathrm{T} 2 *$ values (SIR), which were not affected by iron deposition, and were considered as normal reference (internal standard). Pancreatic iron overload may be considered when the pancreas/paravertebral musculature (SIR) in thalassemic patients $<1^{(13)}$.

\section{Phantom measurements}

The precision and accuracy of T2* MRI measurements were assessed by measuring a series of $\mathrm{MnCl} 2$ solutions with different concentrations, as previously described, for phantom calibration ${ }^{(7,10,11)}$. Measurements of T2* for a series of ten aqueous $\mathrm{MnCl}_{2}$ phantoms with a range of ionic concentrations resulting in theoretical $\mathrm{T} 2 *$ values from 1 to 24 ms were made in the scanners at CHLA (one scanner) and HIAE (three scanners).

\section{Liver biopsy, ferritin levels and LPI}

In order to perform an internal validation, 11 thalassemic patients (aged 12 to 23 years), who were indicated by their physicians to perform liver biopsy to investigate iron overload or other liver lesions, underwent MRI T2* study. The samples were soaked in paraffin and assessed by Centre Hospitalier Universitaire de Rennes, Laboratoire de Biochimie Pr. A. Le Treut Rennes, France. Samples were separated from the paraffin block by xylene impregnation. The quantification of iron concentration by gram of dry liver tissue was performed using atomic absorption spectrometry, according to the method by Barry and Sherlock ${ }^{(14)}$.

Before MRI, patients had blood samples collected to determine ferritin serum levels and LPI.

Serum ferritin dosage was carried out by chemoluminescence (normal range 10 to $291 \mathrm{ng} / \mathrm{mL}$ ). The mean ferritin dosage for the previous 6 months was used for statistical analysis.

The levels of LPI were measured using the fluorescence method. The normal range for LPI is $<0.6 \mu \mathrm{M}^{(15)}$.

\section{Study limitations}

To minimize intra-observer errors, all tests were analyzed by two radiologists who mutually agreed to the calculation of MRI T2*. Should there have been artifacts that prevented the analyses, the values were not recorded.

There were some cases in which it was impossible to carry out LPI because of deliveries to the reference center or inappropriate samples. For this reason, not all patients have results for the dosage.

\section{Statistical analysis}

The statistical analyses and figures used software Statistical Package for Social Sciences (SPSS $^{\circledR}$ for Windows ver. 17.0) and Microsoft ${ }^{\circledR}$ Office Excel 2003.

Data were presented as mean \pm 1 standard deviation. Nonlinear regression analyses were used to define the correlation between hepatic iron concentration in the liver biopsy and liver T2* measures. Pearson and Spearman correlation coefficients were used to define the correlation grade between $\mathrm{T}_{2}^{*}$ values in the heart, liver, pancreas, between themselves, and the correlation between $\mathrm{T}^{*}$ in these organs and serum ferritin levels and LPI. 
Mann-Whitney test was used to assess the significance level between the different studied parameters.

\section{RESULTS}

Upon analyzing the hepatic iron concentration values found in the liver biopsies and correlating them to MRI $\mathrm{T} 2 *$ values, we found an inverse nonlinear correlation between liver $\mathrm{T}_{2}^{*}$ values and iron concentration measured by liver biopsy in the sample of 11 patients who were biopsied $(\mathrm{r}=-0.878 ; \mathrm{p}<0.001)$ (Figure 1A). In logarithmic scale, the measures were highly correlated (the higher the $\log$ of $\mathrm{T} 2 *$, the lower the iron concentration). Therefore, it was possible to satisfactorily estimate iron concentration based on MRI $\mathrm{T} 2 *$ values. According to the linear regression model, each time one $\log$ is added to $\mathrm{T}_{2}^{*}$, there is reduction of 1.12 units in the log of hepatic iron concentration HIC (confidence interval of 95\% - 95\%CI: 0.73-1.51) (Figure 1B). These were important data to validate the methodology determined by the study, given that they demonstrated it was possible to reproduce previous studies.

The study assessed 115 patients with beta-thalassemia major and intermedia. Out of the total, 50 (43.4\%) were male and $65(56.6 \%)$ were female. The mean age was 21.25 years ( 7 to 54 years).

Iron overload was defined by $\mathrm{T} 2 *$ values in the liver, heart and pancreas: $\mathrm{T}^{*}<6.3 \mathrm{~ms}, \mathrm{~T}^{*}<20 \mathrm{~ms}$ and $\mathrm{T} 2 *<21 \mathrm{~ms}$, respectively, considering values defined by previously published studies ${ }^{(5,10)}$.

Mean values of T2* measured in the liver were 3.91 $\pm 3.95 \mathrm{~ms}$. One hundred and five patients $(92.1 \%)$ of a total of 114 assessments of mean liver T2* presented overload in the organ. Converting these values into
HIC using the formula HIC $=\mathrm{R} 2 * \times 0.0254+0.202$, being $\mathrm{R} 2 *=1 / \mathrm{T} 2 * \times 1000$, we obtained HIC values that ranged from 1.0 to $42.5 \mathrm{mg} / \mathrm{g}$ of dry weight. Mean values of HIC were $9.8 \pm 5.2 \mathrm{mg} / \mathrm{g}$ of dry weight. In this case, iron overload affected 114 patients (97.3\%), considering liver overload as HIC values $>2.0 \mathrm{mg} / \mathrm{g}$ of dry weight. We have classified hepatic liver overload according to HIC in MG/g of dry weight as mild (HIC: 2.0-5.6), moderate (HIC: 5.7-11.2) and severe (HIC > 11.2). Our data have shown that 19 patients $(16.6 \%)$ presented mild overload, $52(45.6 \%)$ had moderate overload, and $40(35 \%)$ had severe iron overload in the liver.

Mean values of $\mathrm{T} 2 *$ measured in the heart of 115 patients were $24.96 \pm 14.17 \mathrm{~ms}$ and the incidence of cardiac siderosis $(\mathrm{T} 2 *<20 \mathrm{~ms})$ was $36 \%(42 / 115)$. Overall, $22(19 \%)$ of the patients out of a total 115 have demonstrated signs of severe overload in the heart, expressed by measures of $\mathrm{T} 2 *<10 \mathrm{~ms}$.

Iron overload was also quite frequent in the pancreas, affecting 91/109 analyzed patients, representing $83.5 \%$ of the studied population. The mean value of $\mathrm{T} 2 *$ in these 109 patients was $11.12 \pm 11.20 \mathrm{~ms}$. The mean values were compiled in table 1 .

Table 1. Mean values of liver, heart and pancreas $\mathrm{T} 2 *(\mathrm{~ms})$ and proportion of affected patients

\begin{tabular}{|c|c|c|c|}
\hline Values & $\begin{array}{c}\text { Liver } \\
\text { Normal } \\
\mathrm{T} 2^{*}>6.3 \mathrm{~ms}\end{array}$ & $\begin{array}{c}\text { Heart } \\
\text { Normal } \\
\mathrm{T}^{*}{ }^{*}>20 \mathrm{~ms}\end{array}$ & $\begin{array}{c}\text { Pancreas } \\
\text { Normal } \\
\mathrm{T}_{2}{ }^{*}>21 \mathrm{~ms}\end{array}$ \\
\hline $\mathrm{T}^{*}{ }^{*}(\mathrm{~ms})$ & $3.91 \pm 3.05$ & $24.96 \pm 14.17$ & $11.12 \pm 11.20$ \\
\hline$\%$ of affected patients & $92.1 \%(105)$ & $36 \%(42) 19 \%(22)^{\S}$ & $83.5 \%(91)$ \\
\hline $\begin{array}{l}\text { Total number of } \\
\text { patients evaluated }^{\#}\end{array}$ & 114 & 115 & 109 \\
\hline
\end{tabular}

Values expressed as mean \pm standard deviation.

${ }^{\S} \mathrm{T}^{*}<10 \mathrm{~ms}-$ severe cardiac overload; * the measures that presented no agreement between the two operators, or situations in which the artifacts hindered measurement of $\mathrm{T} 2^{*}$ were not recorded.
A

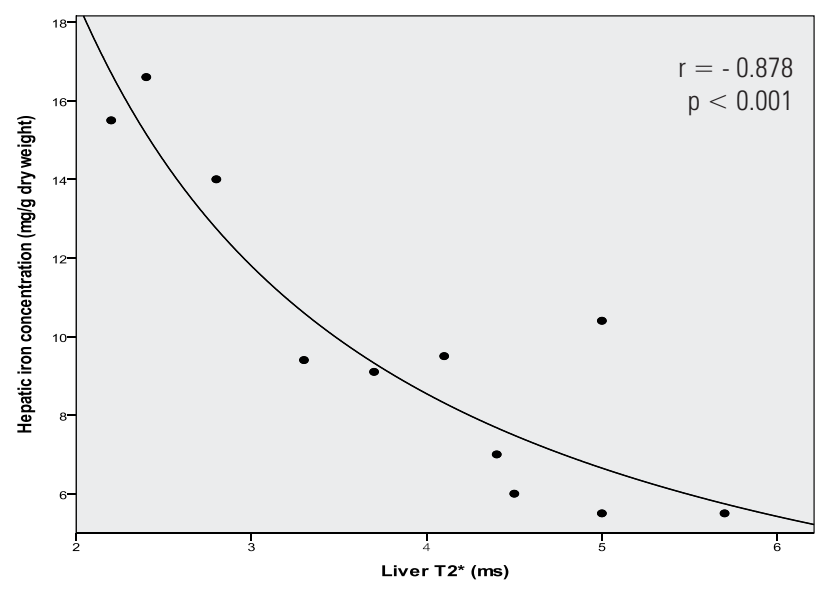

B

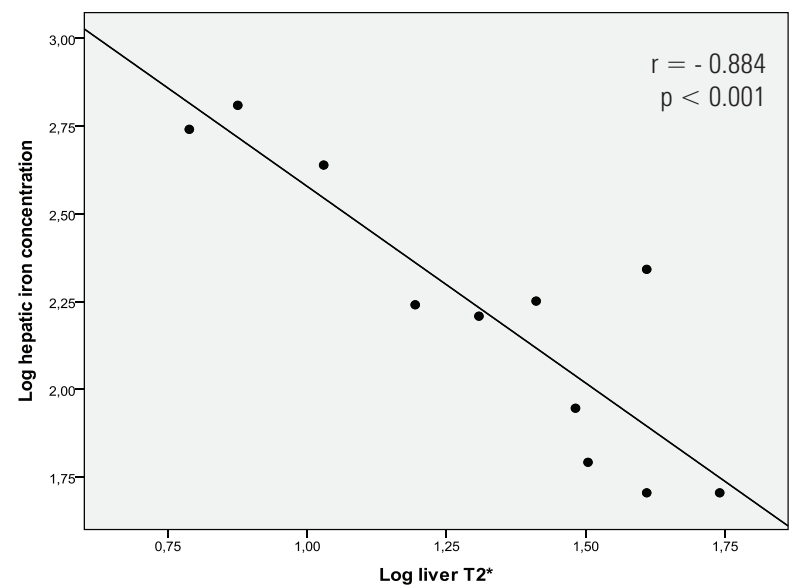

Figure 1. (A) Regression curve demonstrating a strong correlation between measurement of liver $\mathrm{T} 2 *$ (ms) and iron concentration in biopsies of hepatic tissue (mg/g dry weight of liver). (B) There is a strong correlation between two variables after log transformation 
Spearman correlation coefficient of $\mathrm{T} 2 *$ values in the liver and pancreas was $r=0.149(\mathrm{p}=0.112)$ and between $\mathrm{T}^{*}$ in the liver and pancreas it was $\mathrm{r}=0.249$ $(p=0.009)$. These values indicate that there was no correlation between liver iron overload and heart or pancreas overload.

Between pancreas and the heart, the correlation coefficient was $\mathrm{r}=0.546(\mathrm{p}<0.0001)$. This value shows that there was a weak correlation between the two organs and the correlation was stronger after the logarithmic transformation of pancreatic T2* (Figure $2 \mathrm{~A}$ and $2 \mathrm{~B})$.

We have divided the population into young subjects ( $\leq 20$ years) and adults (21 years) and analyzed whether there were differences in the affected organs based on age range. The groups were practically identical, with 58 patients aged up to 20 years and 57 subjects aged over 21 years. Liver, heart and pancreas $\mathrm{T} 2 *$ values did not show increase with aging and both populations were equally affected. The values are shown in table 2 .

Table 2. Values of liver, heart and pancreas $\mathrm{T}^{*}(\mathrm{~ms})$ per age groups (young and adult subjects)

\begin{tabular}{lccc}
\hline T2* $^{*}(\mathbf{m s})$ & $\begin{array}{c}\text { Adults }(>\mathbf{2 1} \\
\text { years })\end{array}$ & $\begin{array}{c}\text { Young subjects } \\
(\leq \mathbf{2 0} \text { years })\end{array}$ & p value* \\
\hline Liver & $4.38 \pm 4.75$ & $3.44 \pm 2.92$ & 0.671 \\
Heart & $24.77 \pm 16.03$ & $25.15 \pm 12.21$ & 0.795 \\
Pancreas & $12.91 \pm 13.83$ & $9.5 \pm 7.88$ & 0.959 \\
\hline
\end{tabular}

Values expressed as mean \pm standard deviation. *Mann-Whitney test.

Mean ferritin serum levels for the previous 6 months ranged from 59 to 12,362 (mean of 2,676.5 $\pm 2,051.7 \mathrm{ng}$ / $\mathrm{mL}$ ). Spearman correlation coefficients were: 0.397 $(\mathrm{p}<0.001)$ between ferritin serum levels and $\mathrm{T} 2 *$ in the liver; $0.220(p=0.019)$ between ferritin and heart $\mathrm{T} 2 *$, and $-0.295(\mathrm{p}=0.002)$ between ferritin and the pancreas. Our results showed that liver, cardiac and pancreatic siderosis cannot be predicted with ferritin serum levels.

The measurement of LPI was made in 83 out of 115 patients. The redox activity of LPI (normal up to $0.6)$ ranged from 0.001 to 11.455 and the results were abnormal in $48 / 83(57 \%)$. Similarly to ferritin, we did not find any correlation between LPI levels and T2* liver, heart and pancreas measures. Pearson correlation coefficient was $-0.259(\mathrm{p}=0.019) ; 0.019(\mathrm{p}=0.866)$ and $-0.022(\mathrm{p}=0.846)$ between LPI and $\mathrm{T} 2 *$ in the liver, heart and pancreas, respectively. Ferritin and LPI did not show correlation one with the other.

\section{DISCUSSION}

Clinical manifestations related with iron overload, clinical signs and symptoms depend on the type of iron overload (primary or secondary), especially on excessive iron, speed of iron store and time of exposure to free iron. The initial symptoms are normally nonspecific and the most commonly reported are fatigue, arthralgia/ arthritis, abdominal pain, decrease in libido or impotence, and weight loss. The most frequent clinical signs upon diagnosis are liver and spleen enlargement, low height and arthropathy. As a result of time and if left untreated, other symptoms and signs may appear, such as portal fibrosis, already observed after 2 years of transfusion; liver cirrhosis and liver failure, and thinning and hyperpigmentation of the skin (resulting from melanin increase in basal layers, linked to skin atrophy). Concerning endocrine manifestations, there are hypogonadotrophic hypogonadism, diabetes mellitus (secondary to excessive iron store in the beta-pancreatic
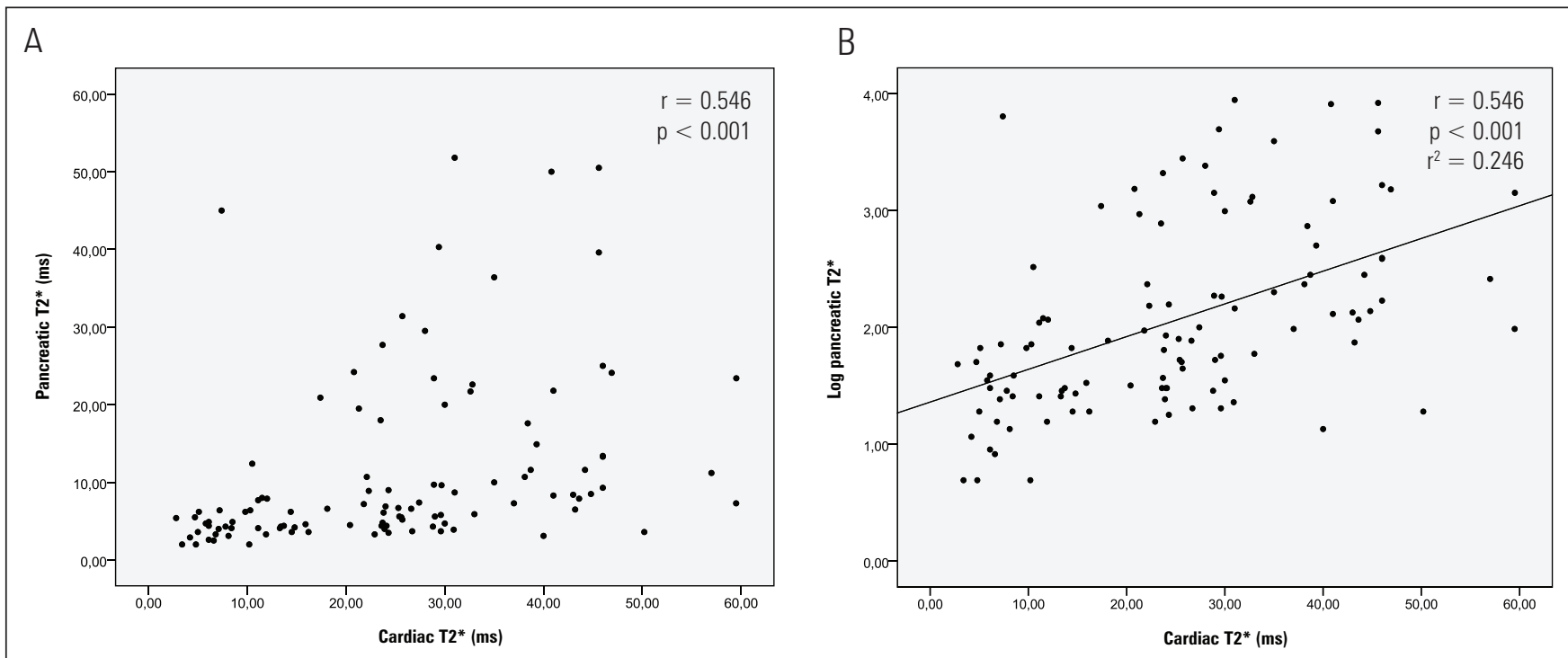

Figure 2. (A) Correlation between cardiac and pancreatic $\mathrm{T} 2^{*}$. (B) Correlation between cardiac $\mathrm{T} 2^{*}$ and log pancreatic $\mathrm{T} 2^{*}$ 
cells and development of resistance to insulin), and hypothyroidism. The main abnormalities related with hypogonadotrophic hypogonadism include: decrease in libido, impotence, amenorrhea, testicular atrophy, gynecomastia, and body hair loss. These abnormalities result primarily in the reduction of gonadotropin synthesis resulting from iron excessive store in the hypophysis and hypothalamus ${ }^{(2,9,13,16)}$.

To present, cardiac complications are still responsible for $54 \%$ of the death in patients with thalassemia major in the United Kingdom. Modell et al., in a recent study, noticed that since the year 2000, there had been significant reduction in all causes of death, especially in those attributed to iron overload. These authors have also emphasized the fact that the use of MRI T2* in medical practice is one of the main factors that have contributed to the decrease in mortality, considering that based on MRI results there has been an increase in use of chelation regimens ${ }^{(5)}$. Thus, the target lethal organ is the heart. Once there is heart failure, the prognosis is poor. Cardiomyopathy may be reverted if chelating therapy is intensified with time, but the diagnosis is frequently delayed owing to the unpredictability of iron stores in the heart, as well as the late onset of symptoms and echocardiographic findings. Early diagnosis of cardiomyopathy using clinical techniques such as echocardiography, electrocardiogram and nuclear medicine has obtained limited success. Dysfunction in general is presented late in the process and the progression of moderate parameters to fulminating failure is often quick and irreversible. Without chelating intensive therapy, these patients may collapse from cardiac or endocrine complications in the second decade of life ${ }^{(17)}$.

The variations of serum ferritin are useful to follow up response to therapy, a relatively cheap and widely available method. However, ferritin may suffer major variations in inflammatory status, which inputs a confounding factor that results in less accurate estimates of total body iron in some patients ${ }^{(9,10,18)}$. Our results have shown, similarly to those in the literature, that ferritin has not presented correlation with MRI findings, which is expected in the heart and pancreatic analyses, but when compared to hepatic values, the literature is discordant given that some authors have presented good correlation between ferritin values and liver overload whereas others have not ${ }^{(7,19-21)}$.

Even though hepatic iron concentration is a good marker to assess total body iron, most toxic actions take place in tissues that get disproportionally impregnated when compared to total body iron. These tissues have different ways to get iron impregnation ${ }^{(22,23)}$. In the endocrine tissue and in the heart, the impregnation is of labile iron particles, not bound to ferritin (NTBI or LPI), whereas the liver captures primarily the iron via transferrin ${ }^{(22)}$. Thus, serum ferritin and hepatic iron values have almost no predictive value for cardiac iron store when assessed transversally ${ }^{(7,8,24)}$.

High hepatic iron concentrations prospectively lead to suspicion of risk. At the same time, low concentrations are not necessarily reassuring. Patients may silently accumulate cardiac iron, even when using appropriate chelation protocols, taking into account the values of serum ferritin and hepatic iron ${ }^{(25,26)}$.

The fact that MRI may detect and monitor silent cardiac impregnation has revolutionized the management of patients with iron overload ${ }^{(5)}$.

The prevalence of left ventricle dysfunction increases progressively as $\mathrm{T} 2 *$ decreases; however, not all patients with $\mathrm{T} 2 *$ below $20 \mathrm{~ms}$ show ejection fraction abnormalities. This information is useful because it means that abnormal $\mathrm{T} 2 *$ represent pre-clinical stages of cardiac iron overload. Westwood et al. demonstrated an increase in prevalence of cardiac dysfunction in patients with short $\mathrm{T} 2 *(27)$.

Practically speaking, $\operatorname{Wood}^{(10)}$ divided patients into three zones based on T2* values. Patients with cardiac T2* above $20 \mathrm{~ms}$ are in the "green zone" and chelation is guided by hepatic concentrations. Patients with T2* between 10 and $20 \mathrm{~ms}$ are in the "yellow zone", in which there had been deposition and there is increased risk of clinical decompensation. The "red zone" gathers patients with $\mathrm{T}^{*}$ below $10 \mathrm{~ms}$, who had eminent risk of clinical decompensation, requiring revision and intensification of the chelation protocol ${ }^{(10)}$.

Our findings are rather alarming because $36 \%$ of the studied subjects already have cardiac iron overload and $19 \%$ of them were in the "red zone" (T2* $<10$ $\mathrm{ms}$ ), considering the critical risk range for irreversible cardiac lesion and complications that may lead to death. In these cases, the information collected by MRI may be used and intensive protocols, as well as combined therapy, should be used to avoid definitive cardiac damage that may progress to myocardial fibrosis ${ }^{(23-25,28)}$.

Endocrine disorders resulting from iron overload are frequent and it is believed that 9 to $15 \%$ of the thalassemic patients will develop diabetes mellitus or glucose intolerance throughout their lives. There is failure of endocrine and exocrine function of the pancreas $^{(9,12,13,29)}$. Similarly to findings in Asian, African and European studies, our data have demonstrated significant impairment of the pancreas with iron $(83 \%$ of affected subjects $)^{(9,12,13,29)}$. When analyzing iron overload in the pancreas in young people and adults, there were no differences, similarly to the findings described by Matter et al., whose patients demonstrated affections before the age of 10 years $^{(29)}$. Argyropoulou et al. have also described lower values of T2 (different technique 
from ours) in young patients compared to adults; their explanation was that there had been very early affection of the organ by iron and, as a consequence, there had been cell death and liposubstitution of pancreatic tissue which could have made $\mathrm{T}^{*}$ values increase rather than decrease. However, they did not show better functional status of the organ, quite to the contrary, it would represent the end stage ${ }^{(9)}$. Despite the fact that it did not have high correlation value, we have noticed that, similarly to other studies, it could predict heart impairment based on pancreatic impairment. In 2009, Noetzli et al. ${ }^{(30)}$ demonstrated that it is possible to predict cardiac siderosis based on MRI findings of the pancreas a decade in advance, which means it would be possible to perform an MRI of the abdomen at lower cost. Unfortunately, our data did not enable us to state that we could perform only an abdominal MRI, as suggested, which would have had substantial economic impact to a developing country such as ours, in which the main healthcare payer is the public healthcare.

LPI is an iron fraction not bound to transferrin (NTBI) but it has recently been considered useful in the control of chelation, given that it has not been possible to determine the correlation between LPI dosage and MRI findings, similarly to our data. The most recent studies have described that after using a chelating therapy, be it deferoxamine or deferasirox, LPI levels should be low for 24 hours, showing that the medication being used is effective not only to excrete excessive iron but also to maintain low levels of free iron in the circulation reducing the toxicity to organs, specially the myocardium and the endocrine system ${ }^{(15,31)}$.

The present study has demonstrated a high rate of hepatic, pancreatic and cardiac impairment by iron overload. It is highlighted that $19 \%$ of the patients have demonstrated $\mathrm{T} 2 *$ levels $<10 \mathrm{~ms}$, which is a source of concern because they are critical levels to cardiac siderosis. This study was relevant to define a current snapshot of the situation of these subjects in relation to iron overload, so that the treatment measures may be enhanced and improved providing longer and better survival of thalassemic patients, similarly to what is observed in other countries.

\section{CONCLUSION}

A high rate of hepatic, pancreatic and cardiacimpairment by iron overload was demonstrated. Ferritin levels could not predict liver, heart or pancreas iron overload as measured by $\mathrm{T} 2 *$ magnetic resonance imaging. There was no correlation between liver, pancreas and myocardial iron overload, neither between ferritin and fraction of labile plasma iron with liver, heart and pancreas $\mathrm{T} 2 *$ values.

\section{ACKNOWLEDGEMENT}

This study carried out by Instituto Israelita de Ensino e Pesquisa Albert Einstein (IIEP) received financial support by the Brazilian Ministry of Health.

This work was supported by Associação Brasileira de Pacientes Talassêmicos (ABRASTA).

We would like to thank Ângela Tavares Paes and Elivane da Silva Victor, from HIAE, for their support to the statistical analysis.

\section{REFERENCES}

1. Li H, Rybicki AC, Suzuka SM, von Bonsdorff L, Breuer W, Hall CB, et al. Transferrin therapy ameliorates disease in beta-thalassemic mice. Nat Med. 2010;16(2):177-82.

2. Cao A, Galanello R. Beta-thalassemia. In: Pagon RA, Bird TC, Dolan CR, Stephens K, editors. GeneReviews [Internet]. Seattle (WA): University of Washington; 2000 Sep 28 [updated 2010 Jun 17; cited 2011 Abr 6]. Available from: http://www.ncbi.nlm.nih.gov/books/NBK1426/

3. Flint J, Harding RM, Boyce AJ, Clegg JB. The population genetics of the haemoglobinopathies. Baillieres Clin Haematol. 1998;11(1):1-51.

4. Associação Brasileira dos Talassemia [Internet]. São Paulo: ABRASTA; [citado 2011 Mar 6]. Disponível em: www.abrasta.org.br

5. Modell B, Khan M, Darlison M, Westwood MA, Ingram D, Pennell DJ. Improved survival of thalassaemia major in the UK and relation to T2* cardiovascular magnetic resonance. J Cardiovasc Magn Reson. 2008; 10:42.

6. Vermylen C. What is new in iron overload? Eur J Pediatr. 2008;167(4):37781.

7. Anderson LJ, Holden S, Davis B, Prescott E, Charrier CC, Bunce NH, et al. Cardiovascular T2-star (T2*) magnetic resonance for the early diagnosis of myocardial iron overload. Eur Heart J. 2001;22(23):2171-9.

8. Wood JC, Tyszka JM, Carson S, Nelson MD, Coates TD. Myocardial iron loading in transfusion-dependent thalassemia and sickle cell disease. Blood. 2004;103(5):1934-6.

9. Argyropoulou MI, Kiortsis DN, Astrakas L, Metafratzi Z, Chalissos N, Efremidis SC. Liver, bone marrow, pancreas and pituitary gland iron overload in young and adult thalassemic patients: a T2 relaxometry study. Eur Radiol. 2007;17(12):3025-30.

10. Wood JC. Magnetic resonance imaging measurement of iron overload. Curr Opin Hematol. 2007;14(3):183-90.

11. St Pierre TG, Clark PR, Chua-anusorn W, Fleming AJ, Jeffrey GP, Olynyk JK, et al. Noninvasive measurement and imaging of liver iron concentrations using proton magnetic resonance. Blood. 2005;105(2):855-61.

12. Au WY, Lam WW, Chu W, Tam S, Wong WK, Liang R, et al. A T2* magnetic resonance imaging study of pancreatic iron overload in thalassemia major. Haematologica. 2008;93(1):116-9.

13. Papakonstantinou O, Ladis V, Kostaridou S, Maris T, Berdousi H, Kattamis $C$, et al. The pancreas in beta-thalassemia major: MR imaging features and correlation with iron stores and glucose disturbances. Eur Radiol. 2007;17(6):1535-43.

14. Barry M, Sherlock S. Measurement of liver-iron concentration in needlebiopsy specimens. Lancet. 1971;1(7690):100-3.

15. Esposito BP, Breuer W, Sirankapracha P, Pootrakul P, Hershko C, Cabantchik ZI. Labile plasma iron in iron overload: redox activity and susceptibility to chelation. Blood. 2003;102(7):2670-7.

16. Cohen A, Galanello R, Pennell DJ, Cunningham MJ, Vichinsky E. Thalassemia. Hematology Am Soc Hematol Educ Program. 2004:14-34. 


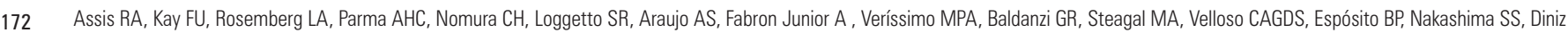
MS, Tricta F, Baroni RH, Funari MBG, Wood JC, Ribeiro AAF, Hamerschlak N

17. Ehlers KH, Levin AR, Markenson AL, Marcus JR, Klein AA, Hilgartner MW, et al. Longitudinal study of cardiac function in thalassemia major. Ann N Y Acad Sci. 1980;344:397-404.

18. Wood JC. Cardiac iron across different transfusion-dependent diseases. Blood Rev. 2008;22 Suppl 2:S14-21.

19. Hankins JS, McCarville MB, Loeffler RB, Smeltzer MP, Onciu M, Hoffer FA, et al. R2* magnetic resonance imaging of the liver in patients with iron overload. Blood. 2009;113(20):4853-5.

20. Kolnagou A, Yazman D, Economides C, Eracleous E, Kontoghiorghes GJ. Uses and limitations of serum ferritin, magnetic resonance imaging $\mathrm{T} 2$ and $\mathrm{T} 2{ }^{*}$ in the diagnosis of iron overload and in the ferrikinetics of normalization of the iron stores in thalassemia using the International Committee on Chelation deferiprone/deferoxamine combination protocol. Hemoglobin. 2009;33(5):31222.

21. Hankins J, Hillenbrand C, Joshi V, Loeffler R, Song R, Ware R, et al. Cardiac $\mathrm{T}^{*}$ magnetic resonance imaging (MRI) in iron overload and ventricular diastolic function. ASH Annual Meeting Abstracts [Internet] 2007 [cited 2011 Mar 23]; 110(11):2676. Available from: http://www.citeulike.org/user/akita/ article/2601835

22. Oudit GY, Sun H, Trivieri MG, Koch SE, Dawood F, Ackerley C, et al. L-type $\mathrm{Ca} 2+$ channels provide a major pathway for iron entry into cardiomyocytes in iron-overload cardiomyopathy. Nat Med. 2003;9(9):1187-94.

23. Anderson LJ, Westwood MA, Holden S, Davis B, Prescott E, Wonke $B$, et al. Myocardial iron clearance during reversal of siderotic cardiomyopathy with intravenous desferrioxamine: a prospective study using $\mathrm{T}^{*}$ cardiovascular magnetic resonance. $\mathrm{Br} \mathrm{J}$ Haematol. 2004; 127(3):348-55.
24. Tanner MA, Galanello R, Dessi C, Westwood MA, Smith GC, Nair SV, et al. Myocardial iron loading in patients with thalassemia major on deferoxamine chelation. J Cardiovasc Magn Reson. 2006;8(3):543-7.

25. Anderson LJ, Westwood MA, Prescott E, Walker JM, Pennell DJ, Wonke B. Development of thalassaemic iron overload cardiomyopathy despite low liver iron levels and meticulous compliance to desferrioxamine. Acta Haematol. 2006;115(1-2):106-8.

26. Wood JC. History and current impact of cardiac magnetic resonance imaging on the management of iron overload. Circulation. 2009;120(20):1937-9.

27. Westood MA, Anderson LJ, Tanner MA, Pennell DJ. The relationship between myocardial iron deposition and left ventricular dysfunction in thalassemia using cardiovascular magnetic resonance [abstract]. J Cardiovasc Magn Reson. 2005,7:46-7.

28. Kolnagou A, Economides C, Eracleous E, Kontoghiorghes GJ. Low serum ferritin levels are misleading for detecting cardiac iron overload and increase the risk of cardiomyopathy in thalassemia patients. The importance of cardiac iron overload monitoring using magnetic resonance imaging T2 and T2*. Hemoglobin. 2006;30(2):219-27.

29. Matter RM, Allam KE, Sadony AM. Gradient-echo magnetic resonance imaging study of pancreatic iron overload in young Egyptian beta-thalassemia major patients and effect of splenectomy. Diabetol Metab Syndr. 2010;2:23.

30. Noetzli LJ, Papudesi J, Coates TD, Wood JC. Pancreatic iron loading predicts cardiac iron loading in thalassemia major. Blood. 2009;114(19):4021-6.

31. Daar S, Pathare A, Nick H, Kriemler-Krahn U, Hmissi A, Habr D, et al. Reduction in labile plasma iron during treatment with deferasirox, a once-daily oral iron chelator, in heavily iron-overloaded patients with beta-thalassaemia. Eur $\mathrm{J}$ Haematol. 2009;82(6):454-7. 